\title{
Skuteczna chemioterapia indukująco-konsolidująca u 20-letniej chorej na ostrą białaczkę promielocytową niewyrażającej zgody na przetoczenia preparatów krwiopochodnych z powodu przekonań religijnych
}

\author{
Successful induction and consolidation chemotherapy \\ in 20-years-old woman with acute promyelocytic leukemia who refused \\ to accept blood transfusion because of religious beliefs
}

\author{
Ilona Szypuła-Perkosz ${ }^{1}$, Ewa Bodzenta ${ }^{1}$, Agnieszka Barchnicka ${ }^{2}$, \\ Elżbieta Chachaj ${ }^{3}$, Janusz Limon ${ }^{4}$, Bożena Jaźwiec ${ }^{5}$, Sebastian Grosicki ${ }^{6}$ \\ ${ }^{1}$ Oddział Hematologiczny, Samodzielny Publiczny Zakład Opieki Zdrowotnej, Zespół Szpitali Miejskich w Chorzowie \\ ${ }^{2}$ Studium Doktoranckie, Wydział Zdrowia Publicznego w Bytomiu, Śląski Uniwersytet Medyczny w Katowicach \\ ${ }^{3}$ Laboratorium Genetyki Klinicznej Uniwersyteckiego Centrum Klinicznego w Gdańsku \\ ${ }^{4}$ Katedra i Zakład Biologii i Genetyki, Gdański Uniwersytet Medyczny \\ ${ }^{5}$ Laboratorium Genetyki Klinicznej, Uniwersyteckie Centrum Kliniczne, Gdańsk \\ ${ }^{6}$ Zakład Profilaktyki Chorób Nowotworowych, Wydział Zdrowia Publicznego w Bytomiu, \\ Śląski Uniwersytet Medyczny w Katowicach
}

\begin{abstract}
Streszczenie
W pracy opisano przypadek 20-letniej chorej na ostra białaczkę promielocytowa, która $z$ powodu przekonań religijnych nie wyrażała zgody na przetaczanie preparatów krwiopochodnych. U pacjentki zastosowano zindywidualizowane leczenie indukujace daunorubicyna, cytarabina, kladrybina $i$ kwasem all-trans retinowym, uzyskujac catkowita remisje (CR). W trakcie chemioterapii indukujacej obserwowano jedynie toksyczność hematologiczna pod postacia leukopenii, niedokrwistości $i$ matoptytkowości 4. stopnia. Po uzyskaniu CR chora otrzymata kolejno trzy kursy chemioterapii konsolidujacej bez istotnych powiktań. W kontrolnym badaniu molekularnym po zakończeniu chemioterapii indukujaco-konsolidujacej nie stwierdzono obecności genu fuzyjnego PML-RARA.
\end{abstract}

Słowa kluczowe: ostra białaczka promielocytowa, chemioterapia, Świadek Jehowy, przetoczenia krwi

Hematologia 2017; 8, 2: 152-158

\begin{abstract}
This paper describes a case of 20 years old woman with acute promyelocytic leukemia who refused to accept blood transfusion because of religious beliefs. Individualized induction chemotherapy with daunorubicin, cladribine, cytarabine and all-trans retinoic acid was administered and complete remission was achieved. Grade 4 leukopenia, anemia and thrombocytopenia was observed during induction chemotherapy. Then three consecutive consolidation cycles were given without important complications. In control molecular analysis after induction-consolidation therapy there was no PML-RARA fusion gene detected.
\end{abstract}

Key words: acute promyelocytic leukemia, chemotherapy, Jehovah's Witness, blood transfusions

Hematologia 2017; 8, 2: 152-158

Adres do korespondencji: Ilona Szypuła-Perkosz, Oddział Hematologiczny, SPZOZ Zespół Szpitali Miejskich w Chorzowie, ul. Strzelców Bytomskich 11, 41-500 Chorzów, e-mail: ilona_sz@poczta.onet.pl 


\section{Wprowadzenie}

Leczenie chorych na ostrą białaczkę szpikową (AML, acute myeloid leukemia), którzy $z$ powodów religijnych nie wyrażają zgody na przetaczanie preparatów krwiopochodnych, stanowi duży problem. W przypadku diagnozy AML u takiego chorego hematolog staje przed dylematem, czy w ogóle podejmować chemioterapię, która $z$ pewnością $w$ konsekwencji przyniesie czasowe pogłębienie cytopenii, czego chory może nie przeżyć. Podejmując decyzję o podaniu chemioterapii, $z$ jednej strony można narazić chorego na skrócenie życia, ale $z$ drugiej strony jest ona jedyną szansą na uzyskanie remisji choroby, przedłużenie życia, a nawet wyleczenie.

Ostra białaczka promielocytowa (APL, acute promyelocytic leukemia) to szczególny podtyp AML. U tych chorych leczenie oparte na kwasie all-trans retinowym (ATRA, all-trans retinoic acid) w skojarzeniu $z$ chemioterapią antracykliną daje szansę na uzyskanie całkowitej remisji (CR) i wyleczenie [1-4]. Dodatkowo w tym podtypie białaczki korzystne może być zastosowanie trójtlenku arsenu (ATO, arsenic trioxide) $[5,6]$. W pracy przedstawiono opis skutecznej chemioterapii indukująco-konsolidującej u 20-letniej chorej na APL, która ze względów religijnych nie wyrażała zgody na przetaczanie preparatów krwiopochodnych.

\section{Opis przypadku}

Pacjentka była diagnozowana na początku sierpnia 2016 roku w Klinice Hematologii Gdańskiego Uniwersytetu Medycznego z powodu narastającego osłabienia, zawrotów głowy, nawracających krwawień z nosa i obserwowanej w morfologii krwi pancytopenii. W wykonanych badaniach dodatkowych stwierdzono w morfologii krwi obwodowej obniżoną do 2,01 G/1 liczbę leukocytów (WBC, white blood cells), stężenie hemoglobiny (Hb) wynoszące $6,9 \mathrm{~g} / \mathrm{dl}$ oraz liczbę płytek krwi (PLT, platelets) równą $15 \mathrm{G} / 1$. W rozmazach krwi obwodowej mieloblasty stanowiły $34,5 \%$ (ryc. 1 ). $\mathrm{W}$ badaniach koagulologicznych stwierdzono: czas protrombinowy (PT, prothrombin time) $15 \mathrm{~s}$, wskaźnik PT 77\%, międzynarodowy wskaźnik znormalizowany (INR, international normalized ratio) 1,32, czas częściowej tromboplastyny po aktywacji (APTT, activated partial thromboplastin time) $30 \mathrm{~s}$, stężenie fibrynogenu $0,86 \mathrm{~g} / \mathrm{l}$. W badaniu immunofenotypowym szpiku wykazano populację komórek atypowych stanowiącą 56\% komórek szpiku i wykazującą następujący immunofenotyp: CD45 ${ }^{\text {dim }}$,

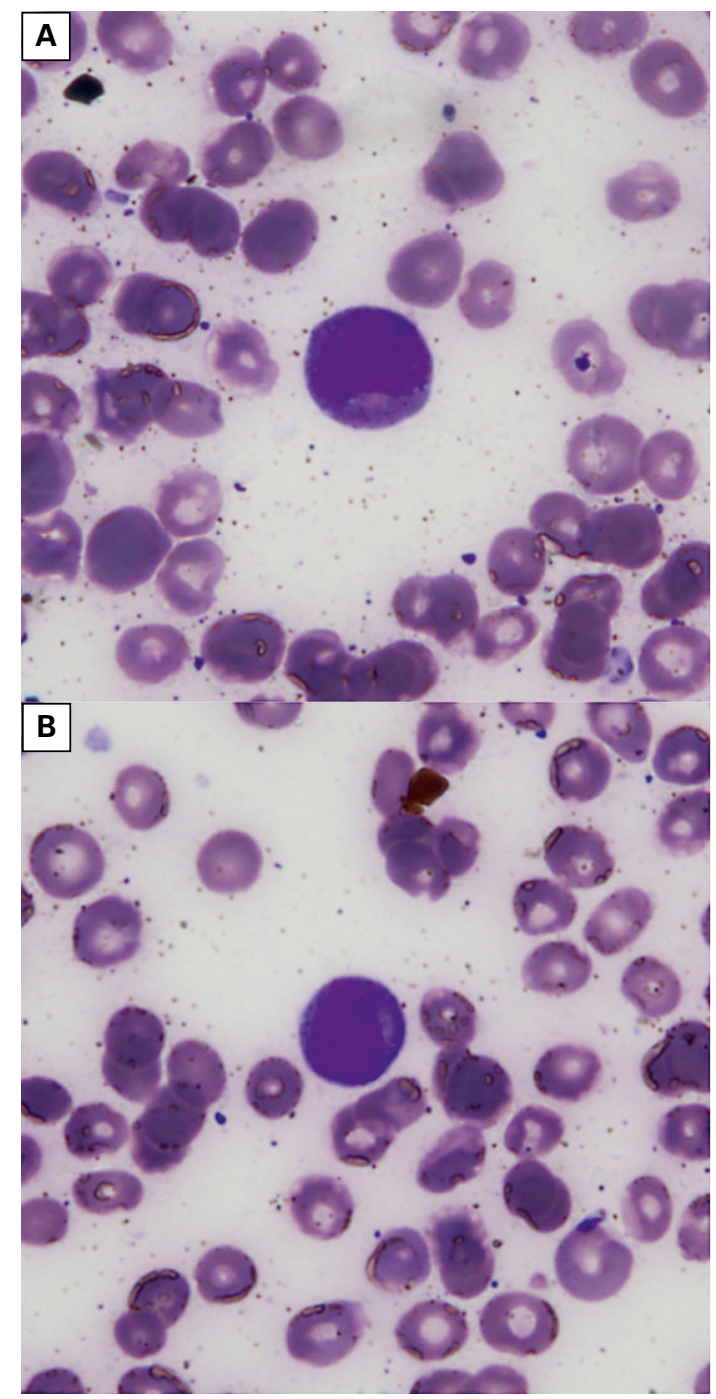

Rycina 1A, B. Promielocyty w rozmazie krwi obwodowej pacjentki (barwienie metodą Maya-Grünwalda-Giemsy, powiększenie $\times 100$ )

Figure 1A, B. Promyelocytes in blood smear of the patient (May-Grünwald-Giemsa staining, $\times 100$ )

$\mathrm{CD} 117+, \mathrm{CD} 33+, \mathrm{cMPO}+, \mathrm{CD} 71+, \mathrm{CD} 13+$, częściowo CD38+, CD34+, słabą ekspresję HLA-DR (human leukocyte antigen-D related). W badaniu cytologicznym szpiku stwierdzono naciek komórkami mieloblastycznymi z zachowanymi w układzie granulocytarnym niewielkimi cechami dojrzewania do promielocytu. Układ granulocytarny stanowił $69 \%$ komórek szpiku, w tym: mieloblasty $55,6 \%$, promielocyty $6,6 \%$, mielocyty $0,6 \%$, metamielocyty $0 \%$, pałeczki $1,8 \%$, segmenty $4,4 \%$. Na podstawie powyższych badań rozpoznano AML z zachowanym dojrzewaniem. Ze względów technicznych nie udało się wykonać badania molekularnego na obecność translokacji $P M L / R A R \alpha$. Pod koniec sierpnia 2016 


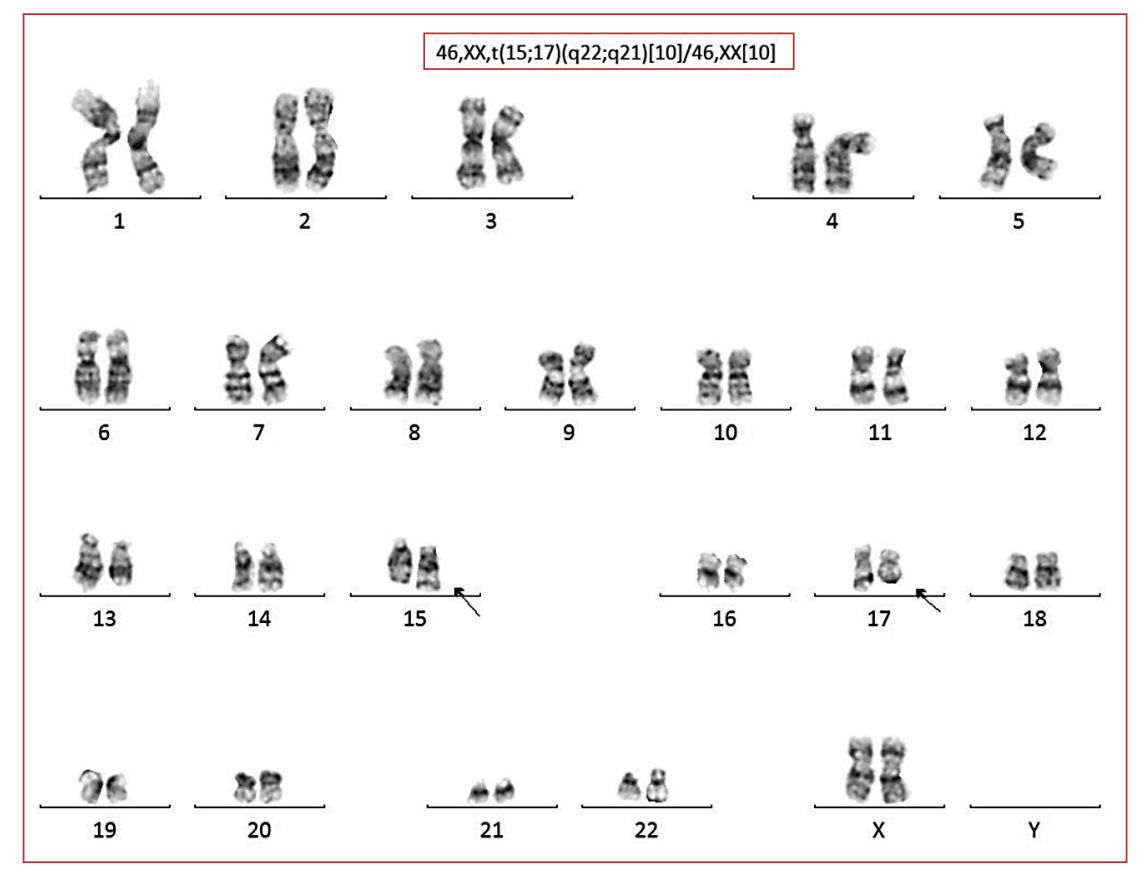

Rycina 2. Kariotyp pacjentki. Strzałką zaznaczono chromosomy z aberracją cytogenetyczną

Figure 2. Karyotype of the patient. The arrow indicates chromosome with cytogenetic aberration

roku uzyskano wynik badania cytogenetycznego, w którym stwierdzono dwa klony komórkowe. W pierwszym (10 metafaz) wykryto translokację wzajemną między chromosomami 15 i $17 \mathrm{t}(15 ; 17)$ (q22;q21), w drugim (10 metafaz) kariotyp prawidlowy (ryc. 2). $Z$ powodu braku zgody pacjentki na przetaczanie preparatów krwiopochodnych, a tym samym — pełnej zgody na leczenie, nie zdecydowano się wówczas na rozpoczęcie chemioterapii.

Przy przyjęciu na Oddział Hematologiczny Zespołu Szpitali Miejskich w Chorzowie 26 sierpnia 2016 roku pacjentka była znacznie osłabiona, ze stwierdzanymi w badaniu przedmiotowym nasilonymi cechami niedokrwistości i licznymi podbiegnięciami krwawymi na skórze kończyn dolnych. W morfologii krwi obwodowej przy przyjęciu stwierdzono liczbę WBC $12,8 \mathrm{G} / \mathrm{l}$, stężenie $\mathrm{Hb} 6,2 \mathrm{~g} / \mathrm{dl}$, liczbę PLT $7 \mathrm{G} / \mathrm{l}$. W rozmazach krwi obwodowej mieloblasty stanowiły $80 \%$, a ich morfologia wskazywała raczej na podtyp M1 według klasyfikacji FAB (French-American-British). W badaniach koagulologicznych stwierdzono: PT 17,3 s, wskaźnik PT — 70,5\%, INR - 1,43, APTT — 30,3 s, stężenie fibrynogenu $-0,64 \mathrm{~g} / \mathrm{l}$. Zważywszy na obniżone stężenie fibrynogenu i nasiloną skazę krwotoczną na skórze pobrano krew na badanie molekularne w kierunku translokacji $P M L-R A R \alpha$, ale, nie czekając na wynik tego badania $z$ powodu pogarszającego się stanu chorej i zdając sobie w peł- ni sprawę, że każdy dzień opóźnienia leczenia zwielokrotnia ryzyko zgonu chorej z powodu rosnącego ryzyka powikłań, w pierwszej dobie hospitalizacji rozpoczęto ratunkowe, zindywidualizowane leczenie chemioterapeutyczne: daunorubicyną $\mathrm{w}$ dawce $40 \mathrm{mg} / \mathrm{m}^{2}$ podawaną dożylnie (i.v., intravenous) (1. dzień), cytarabiną w dawce $100 \mathrm{mg} / \mathrm{m}^{2}$ podawaną c.i. (1.-3. dzień), kladrybiną w dawce $5 \mathrm{mg} / \mathrm{m}^{2}$ podawanąi.v. (1.-3. dzień). Zadecydowano o zakończeniu chemioterapii indukującej po 3 dniach, biorąc pod uwagę bardzo korzystny efekt w postaci leukopenii po tak krótkim okresie leczenia, ale również $z$ powodu pogłębiającej się anemizacji. Nie dysponowano wówczas wynikiem badania cytogenetycznego wykonanego wcześniej w innym ośrodku. Wynik badania molekularnego potwierdzający obecność genu fuzyjnego $P M L-R A R \alpha$, typ transkryptu BCR3 (metodą reakcji łańcuchowej polimerazy w czasie rzeczywistym [RT-PCR real-time polymerase chain reaction]) (ryc. 3), uzyskano w 7 . dobie leczenia i tego dnia rozpoczęto stosowanie ATRA w dawce $25 \mathrm{mg} /$ $/ \mathrm{m}^{2}$ doustnie (p.o., per os). $\mathrm{W}$ trakcie chemioterapii obserwowano stany gorączkowe, przejściowe bóle głowy i biegunki. W leczeniu wspomagającym stosowano tlenoterapię bierną. W celu zahamowania krwawienia miesiączkowego zastosowano linestrenol.

Stężenie Hb od 4. do 15. doby leczenia utrzymywało się poniżej $4 \mathrm{~g} / \mathrm{dl}$, osiągając najniższe stężenie w 7. dobie leczenia (3,3 g/dl) (ryc. 4). Liczba 


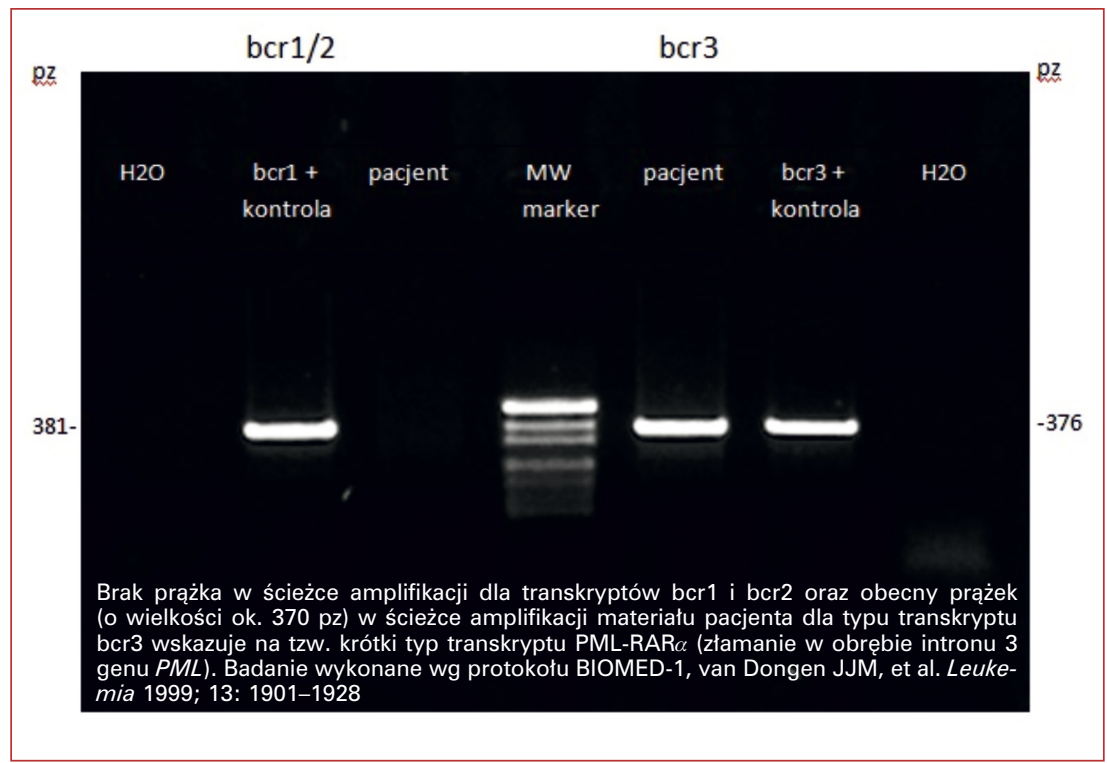

Rycina 3. Obraz żelu elektroforetycznego (agaroza/bromek etydyny) pokazującego fuzję genów $P M L-R A R \alpha$

Figure 3. Image of electrophoretic gel (agarose/ethidium bromide) showing $P M L-R A R \alpha$ fusion gene

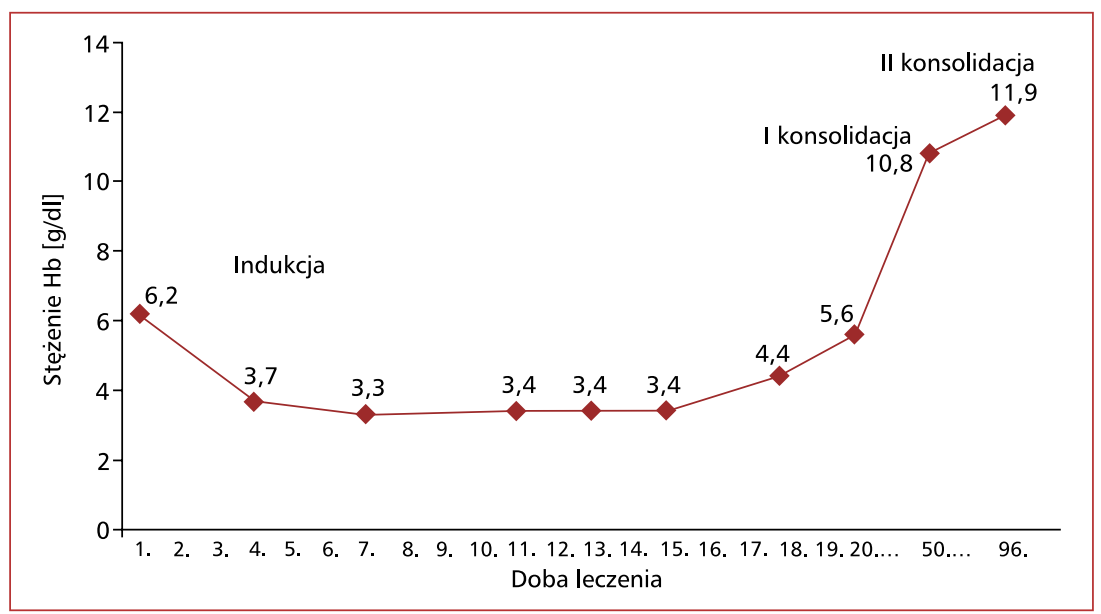

Rycina 4. Stężenie hemoglobiny $(\mathrm{Hb}) \mathrm{w}$ trakcie leczenia

Figure 4. Hemoglobin $(\mathrm{Hb})$ concentration during therapy

PLT na początku leczenia wynosiła poniżej $10 \mathrm{G} / \mathrm{l}$; jej istotny wzrost - do $26 \mathrm{G} / 1$ - zaobserwowano w 13. dobie leczenia (ryc. 5). Liczba WBC obniżyła się z 12,8 G/l (liczba neutrofilów 2,63 G/1) w 1. dobie leczenia do 0,7 G/l (liczba neutrofilów 0,38 G/l) w 4. dobie leczenia, osiągając najniższą wartość 0,5 G/1 (liczba neutrofilów 0,11 G/l) w 7. dobie (ryc. 6). $\mathrm{W}$ kontrolnej morfologii w 20. dobie leczenia parametry morfologii wyraźnie się poprawiły i były następujące: liczba WBC 0,9 G/l, stężenie Hb 5,6 g/ /dl, liczba PLT $203 \mathrm{G} / 1$. W 21. dobie leczenia pacjentkę wypisano do domu $\mathrm{z}$ zaleceniem kontynuowania stosowania ATRA w dawce $25 \mathrm{mg} / \mathrm{m}^{2}$ p.o.
13 października 2016 roku pacjentka została ponownie przyjęta na oddział hematologiczny w celu oceny efektu chemioterapii indukującej oraz kontynuacji leczenia. W trakcie pobytu w domu nie obserwowano powikłań. Samopoczucie pacjentki było dobre. W morfologii krwi obwodowej przy przyjęciu stwierdzono: liczbę WBC 3,7 G/1, stężenie $\mathrm{Hb}$ 10,8 g/dl, liczbę PLT $438 \mathrm{G} / \mathrm{l}$. W rozmazach krwi obwodowej nie stwierdzono obecności mieloblastów. W ocenie cytologicznej aspiratu szpiku kostnego mielogram opisano jako prawidłowy. U chorej potwierdzono CR. W badaniach koagulologicznych nie wykazano odchyleń od stanu prawidłowego. 


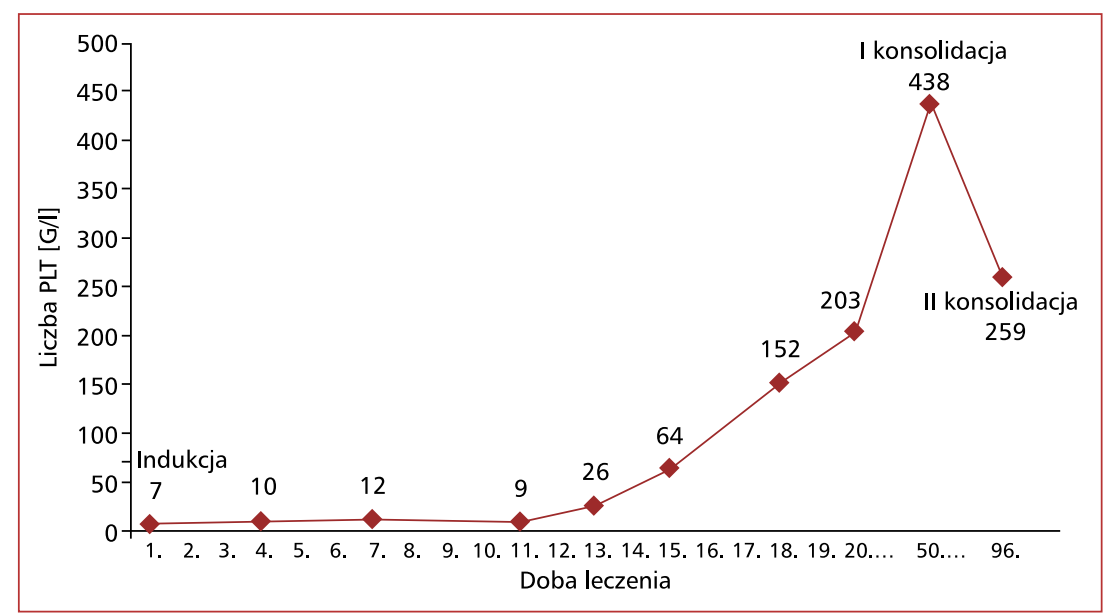

Rycina 5. Liczba płytek krwi (PLT) w trakcie leczenia

Figure 5. Platelet (PLT) count during therapy

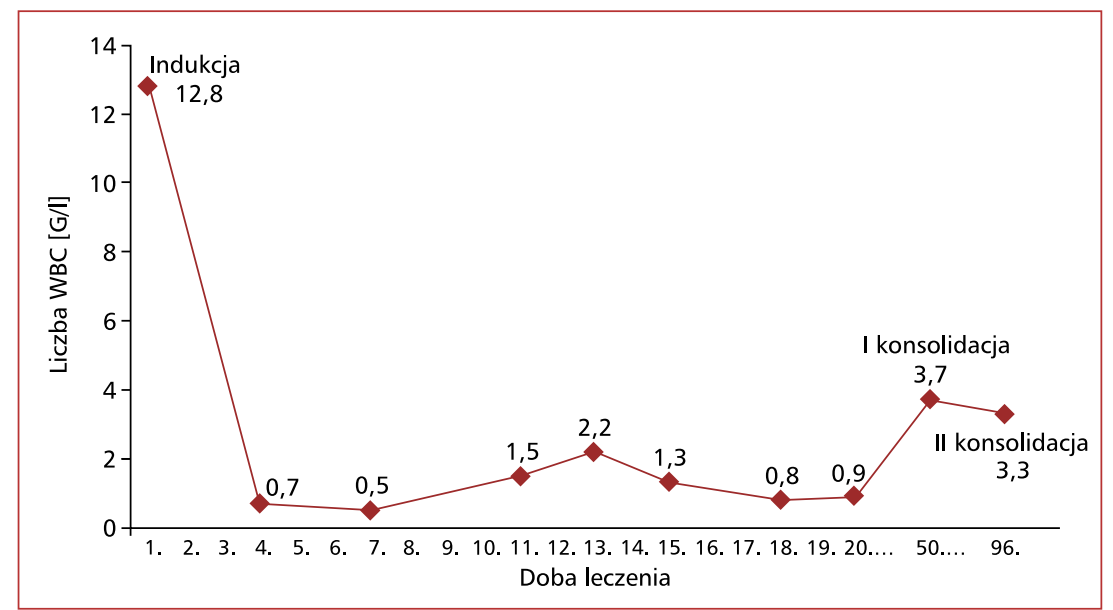

Rycina 6. Liczba białych krwinek (WBC) w trakcie leczenia

Figure 6. White blood cells (WBC) count during therapy

Zdecydowano o podaniu pierwszego leczenia konsolidującego: idarubicyny w dawce $6,7 \mathrm{mg} / \mathrm{m}^{2} i . v$. (1.-4. dzień), ATRA w dawce $25 \mathrm{mg} / \mathrm{m}^{2}$ p.o. (1.-15. dzień). W kontrolnych badaniach $\mathrm{w}$ trakcie leczenia nie obserwowano istotnego obniżenia parametrów morfotycznych krwi i w 6 . dobie leczenia konsolidującego pacjentkę wypisano do domu w dobrym stanie ogólnym. W morfologii krwi obwodowej przy wypisaniu odnotowano: liczbę WBC $3 \mathrm{G} / 1$, stężenie Hb 9,7 g/dl, liczbę PLT 316 G/l.

28 listopada 2016 roku pacjentka w dobrym stanie ogólnym została planowo przyjęta na oddział hematologiczny, by można było zastosować drugie leczenie konsolidujące. W morfologii krwi obwodowej przy przyjęciu stwierdzono: liczbę WBC 3,3 G/l, stężenie Hb 11,9 g/dl, liczbę PLT 259 G/l. W roz- mazach krwi obwodowej nie stwierdzono obecności mieloblastów. Zdecydowano o podaniu kolejnej chemioterapii konsolidującej: mitoksantronu w dawce $9 \mathrm{mg} / \mathrm{m}^{2} i . v$. na dobę $\mathrm{w}$ dniach 1.-3., ATRA w dawce $25 \mathrm{mg} / \mathrm{m}^{2}$ p.o. na dobę w dniach 1.-15. Pacjentkę wypisano do domu w dobrym stanie ogólnym w 4 . dobie drugiego leczenia konsolidującego.

Trzeci cykl chemioterapii konsolidującej rozpoczęto 28 grudnia 2016 roku. W chemioterapii zastosowano: idarubicynę w dawce $9,5 \mathrm{mg} / \mathrm{m}^{2}$ i.v. (1. dzień), cytarabinę w dawce $95 \mathrm{mg} / \mathrm{m}^{2}$ i.v. (1.-3. dnia), ATRA w dawce $25 \mathrm{mg} / \mathrm{m}^{2}$ po (1.-15. dnia). W wykonanym po zakończeniu konsolidacji badaniu szpiku nie stwierdzono cech nacieku mieloblastami. W kontrolnym badaniu molekularnym nie wykazano obecności genu fuzyjnego $P M L-R A R \alpha$. 


\section{Dyskusja}

W przypadku pojawiającej się po chemioterapii pancytopenii, która jest skutkiem uszkodzenia hematopoezy przez nowotwór hematologiczny, jak również zastosowanej chemioterapii, zaleca się substytucję preparatów krwiopochodnych w celu obniżenia ryzyka powikłań wynikających $z$ głębokiego deficytu PLT i Hb. Grupa PETHEMA w swoich badaniach u chorych na APL ze stwierdzoną koagulopatią zalecała przetaczanie preparatów płytek krwi, by utrzymać liczbę PLT powyżej $30 \mathrm{G} / 1$ do czasu ustapienia koagulopatii [1]. W opisanym przypadku u chorej równocześnie występowały cechy skazy krwotocznej związane $z$ wykrzepianiem wewnątrznaczyniowym oraz głęboką małopłytkowością poniżej 10 G/l. Mimo dużego ryzyka spowodowanego głęboką małopłytkowością w trakcie leczenia nie doszło do zagrażającego życiu krwawienia. Kolejnym problemem była nasilająca się niedokrwistość. U chorej najniższe stężenie Hb obserwowano w 7. dobie i wynosilo ono $3,3 \mathrm{~g} / \mathrm{dl}$. Najniższą wartością $\mathrm{Hb}$ opisaną w literaturze, którą pacjent przeżył i którą obserwowano u osoby niewyrażającej zgody na przetoczenia preparatów krwiopochodnych $z$ powodu przekonań religijnych $\mathrm{w}$ trakcie chemioterapii $\mathrm{z}$ powodu ostrej białaczki limfoblastycznej (ALL, acute lymphoblastic leukemia), była wartość 1,3 g/dl [7].

Leczenie chemioterapią pacjentów niezgadzających się na przetoczenia preparatów krwiopochodnych stwarza wiele problemów. Jednak w piśmiennictwie są doniesienia o udanych chemioterapiach indukujących u Świadków Jehowy, które dotyczą przeważnie pacjentów chorujących na ALL i APL, a w mniejszym odsetku na AML [8-11]. W przypadku chorych na APL i niewyrażających zgody na przetaczanie preparatów krwiopochodnych można znaleźć pojedyncze doniesienia o wieloletnich przeżyciach po zastosowaniu leczenia [12]. Opisano także przypadek pacjentki będącej Świadkiem Jehowy, u której rozpoznano APL na początku ciąży - po zastosowaniu ATRA w monoterapii pacjentka osiągnęła $\mathrm{CR}$ i, mimo przejściowej głębokiej anemii (stężenie Hb 3,7 g/dl), urodziła zdrowe dziecko [13]. $\mathrm{W}$ piśmiennictwie są także doniesienia o przeprowadzeniu udanych przeszczepień allogenicznych krwiotwórczych komórek macierzystych szpiku u pacjentów $z$ AML niewyrażających zgody na przetoczenia preparatów krwiopochodnych [14].

\section{Podsumowanie}

Zarówno opisany w niniejszej pracy przypadek, jak i przytoczone wyżej przykłady sukcesów terapeutycznych u pacjentów chorujących na AML i niewyrażających zgody na przetoczenia preparatów krwiopochodnych nie zmieniają faktu, że rokowanie u tych chorych jest skrajnie złe, a decyzje terapeutyczne pozostają bardzo trudne. Wydaje się jednak, że, czerpiąc $z$ doświadczeń własnych, jak i innych lekarzy zajmujących się leczeniem chorych na ostre białaczki, nie można rezygnować $z$ próby leczenia, szczególnie chorych młodych, nawet jeżeli nie można się wspomagać substytucją preparatów krwiopochodnych, ponieważ niepodjęcie leczenia z całą pewnością skończy się zgonem chorego. Opisany przypadek ukazuje, że warto podejmować ryzyko terapeutyczne w sytuacjach trudnych, dając szansę choremu.

\section{Piśmiennictwo}

1. Sanz MA, Montesinos P, Kim HT, et al. IC-APL and PETHEMA and HOVON Groups. All-trans retinoic acid with daunorubicin or idarubicin for risk-adapted treatment of acute promyelocytic leukaemia: a matched-pair analysis of the PETHEMA LPA-2005 and IC-APL studies. Ann Hematol. 2015; 94(8): 1347-1356, doi: 10.1007/s00277-015-2393-0, indexed in Pubmed: 25975975.

2. Sanz MA, Martín G, González M, et al. Programa de Estudio y Traitmiento de las Hemopatías Malignas. Risk-adapted treatment of acute promyelocytic leukemia with all-trans-retinoic acid and anthracycline monochemotherapy: a multicenter study by the PETHEMA group. Blood. 2004; 103(4): 1237-1243, doi: 10.1182/ /blood-2003-07-2462, indexed in Pubmed: 14576047.

3. Sanz MA, Montesinos P, Vellenga E. Risk-adapted treatment of acute promyelocytic leukemia with all-trans retinoic acid and anthracycline monochemotherapy: long-term outcome of the LPA 99 multicenter study by the PETHEMA Group. Blood. 2008; 112(8): 3130-3134, doi: 10.1182/blood-2008-05-159632, indexed in Pubmed: 18664623.

4. Tallman MS, Nabhan C, Feusner JH, et al. Acute promyelocytic leukemia: evolving therapeutic strategies. Blood. 2002; 99(3): 759-767, indexed in Pubmed: 11806975.

5. Platzbecker U, Avvisati G, Cicconi L, et al. Improved outcomes with retinoic acid and arsenic trioxide compared with retinoic acid and chemotherapy in non-high-risk acute promyelocytic leukemia: final results of the randomized Italian-German APL0406 trial. J Clin Oncol. 2017; 35(6): 605-612, doi: 10.1200/JCO.2016.67.1982, indexed in Pubmed: 27400939.

6. Burnett AK, Russell NH, Hills RK, et al. UK National Cancer Research Institute Acute Myeloid Leukaemia Working Group. Arsenic trioxide and all-trans retinoic acid treatment for acute promyelocytic leukaemia in all risk groups (AML17): results of a randomised, controlled, phase 3 trial. Lancet Oncol. 2015; 16(13): 1295-1305, doi: 10.1016/S1470-2045(15)00193-X, indexed in Pubmed: 26384238.

7. Chojnowski K, Janus A, Bliźniewska K, et al. Long-lasting extreme anemia during the therapy of acute lymphoblastic leukemia in a Jehovah's Witness patient. Transfusion. 2016; 56(10): 2438-2442, doi: 10.1111/trf.13703, indexed in Pubmed: 27385671.

8. Laszlo D, Agazzi A, Goldhirsch A, et al. Tailored therapy of adult acute leukaemia in Jehovah's Witnesses: unjustified reluctance to treat. Eur J Haematol. 2004; 72(4): 264-267, doi: 10.1111/j.09024441.2003.00211.x, indexed in Pubmed: 15089764. 
9. Brown NM, Keck G, Ford PA. Acute myeloid leukemia in Jehovah Witnesses. Leuk Lymphoma. 2008; 49(4): 817-820, doi: 10.1080/10428190801911670, indexed in Pubmed: 18398752.

10. Cullis JO, Duncombe AS, Dudley JM, et al. Acute leukaemia in Jehovah's Witnesses. Br J Haematol. 1998; 100(4): 664-668, indexed in Pubmed: 9531331.

11. Mazza P, Palazzo G, Amurri B, et al. Acute leukemia in Jehovah's Witnesses: a challenge for hematologists. Haematologica. 2000; 85(11): 1221-1222, indexed in Pubmed: 11064477.

12. Keane C, Mollee P, Marlton P, et al. Treatment of acute promyelocytic leukaemia in the Jehovah's Witness population. Ann
Hematol. 2011; 90(3): 359-360, doi: 10.1007/s00277-010-1023-0, indexed in Pubmed: 20607537.

13. Lin CP, Huang MJ, Liu HJ, et al. Successful treatment of acute promyelocytic leukemia in a pregnant Jehovah's Witness with all-trans retinoic acid, rhG-CSF, and erythropoietin. Am J Hematol. 1996; 51(3): 251-252, doi: 10.1002/(SICI)1096-8652(199603)51:3<251::AIDAJH20 > 3.0.CO;2-I, indexed in Pubmed: 8619417.

14. Wandt H, Schaefer-Eckart K, Wilhelm M. Two allogeneic hematopoietic stem cell transplantations without the use of blood-product support. Haematologica. 2005; 90(9): 1292-1294, indexed in Pubmed: 16154863. 